\title{
PENINGKATAN KETERAMPILAN MENULIS KARANGAN DENGAN MENGGUNAKAN MEDIA GAMBAR BERSERI PADA SISWA KELAS III SDN SUNGAI ANDAI I BANJARMASIN
}

\author{
Improving Skill Of Writing Analysis Using Cerricate Image Media In Class III Students Of \\ SDN Sungai Andai I Banjarmasin
}

\section{Ihsan Ramadhani ${ }^{*}$}

Rizal Fuady ${ }^{2}$

\author{
*,Universitas Achmad Yani, \\ Banjarmasin, Kalimantan \\ Selatan, Indonesia \\ 2 Universitas Achmad Yani, \\ Banjarmasin, Kalimantan \\ Selatan, Indonesia \\ ${ }^{3}$ Afiliasi Penulis 3, Kota, \\ Provinsi, Negara \\ *email: ihsandikdas@uay.ac.id
}

\section{Kata Kunci:}

Menulis karangan, Media

Gambar Berseri

\section{Keywords:}

Writing essays

Serial Image Media

\begin{abstract}
Abstrak
Penelitian ini bertujuan untuk mengetahui pengunaan media gambar berseri dalam meningkatkan keterampilan menulis karangan pada siswa kelas III SDN Sungai Andai I Kota Banjarmasin. Metodologi penelitian ini menggunakan penelitian kelas digunakan (PTK) yang dilaksanakan dengan dua siklus pada mata pelajaran Bahasa Indonesia dengan subyek siswa kelas III. Jenis data yang digunakan dalam penelitian ini adalah kuantitatif dan kualitatif. Analisis data dilakukan dengan teknis persentase penilaian skala dan indikator keberhasilan ketuntasan. Hasil penelitian menunjukkan bahwa pelaksanaan aktivitas guru menggunakan media gambar berseri telah berhasil, terlihat pada siklus pertama mendapatkan persentase 79,68\% dengan kategori baik meningkat pada siklus kedua, menjadi $85,93 \%$ dengan kategori sangat baik. Hasi belajar keterampilan menulis karangan menggunakan media gambar berseri telah terlaksana dengan sangat baik, terlihat pada siklus I memperoleh persentase ketuntasan 7I,42\% dengan kategori cukup aktif meningkat pada siklus II mencapai $85,71 \%$ dengan kategori sangat aktif.
\end{abstract}

\begin{abstract}
This study aims to determine the use of serial image media in improving essay writing skills in grade III SDN Sungai Andai I Banjarmasin City. Methodology this study used classroom research which was carried out in two cycles on Indonesian subjects with grade III student subjects. The types of data used in this research are quantitative and qualitative. The data analysis was carried out by using the technical percentage scale assessment and completion success indicators. The results showed that the implementation of teacher activities using serial picture media was successful, it can be seen that in the first cycle the percentage of $79.68 \%$ in the good category increased in the second cycle, to $85.93 \%$ in the very good category. The results of learning essay writing skills using serial image media have been carried out very well, it can be seenin the first cycle, the completeness percentage was $71.42 \%$ with the fairly active category, increasing in the second cycle it reached $85.71 \%$ with the very active category.
\end{abstract}

Accepted

September 2020

Published

December 2020
(C) 2020 The Authors. Published by Institute for Research and Community Services Universitas Muhammadiyah Palangkaraya. This is Open Access article under the CC-BY-SA License (http://creativecommons.org/licenses/by-sa/4.0/).

\section{PENDAHULUAN}

Pendidikan adalah usaha sadar dan terencana guna mewujudkan suasana belajar dan proses pembelajaran secara aktif untuk mengembangkan potensi peserta didik agar memiliki kecerdasan spiritual keagamaan, pengendalian diri, dan semua keterampilan yang dibutuhkan untuk dirinya, masyarakat, bangsa dan Negara, dimana hal tersebut secara tersirat sudah menjadi tujuan pendidikan itu sendiri. Ramadhani \& Fuady (2020:103) menyatakan bahwa pendidikan merupakan sarana penting untuk meningkatkan kualitas sumber daya manusia (SDM) dalam menjamin keberlangsungan pembangunan suatu bangsa. Oleh karena itu salah satu upaya untuk mewujudkan tujuan pendidikan di sekolah dasar adalah dengan melalui proses pembelajaran dari berbagai 
satuan mata pelajaran di tingkat sekolah dasar. Salah satu mata pelajaran di sekolah dasar yaitu Bahasa Indonesia. Mata Pelajaran Bahasa Indonesia memiliki empat keterampilan yang harus dikuasai oleh siswa yaitu : keterampilan membaca, keterampilan berbicara, keterampilan menyimak dan keterampilan menulis.

Keterampilan menulis sebagai salah satu bagian dari empat keterampilan berbahasa, mempunyai peran yang penting di dalam kehidupan manusia. Dalman (201 I:6) menulis mempunyai manfaat seperti meningkatkan kecerdasan, pengembangan daya inisiatif dan kreativitas, penumbuhan keberanian, serta pendorong kemampuan dan kemampuan informasi. Menulis juga sebagai sarana penyampaian pesan atau gagasan kepada orang lain sehingga orang tersebut paham dengan pesan atau gagasan yang ingin disampaikan. Setiap manusia, semuanya diciptakan sebagai pengarang dan mempunyai keterampilan menulis, dimana penguasaan keterampilan menulis karangan tidak diperoleh secara alamiah akan tetapi membutuhkan latihan yang intensif dan membutuhkan proses berkelanjutan. Proses berlatih menulis karangan tersebut dapat dilakukan oleh siswa secara formal melalui pembelajaran Bahasa Indonesia yang dimulai sejak Sekolah Dasar.

Berdasarkan kenyataan bahwa menulis karangan tidak diperoleh secara alamiah, maka peneliti melakukan observasi langsung di SDN Sungai Andai I Kota Banjarmasin pada tanggal 30 Juli 2019, dengan hasil observasi siswa di sekolah tersebut cenderung kurang terampil dalam menulis karangan pada pembelajaran Bahasa Indonesia dikarenakan siswa kurang mampu dalam memilih kata dalam menuangkan buah pikirnya, di samping itu siswa yang mengikuti pelajaran kurang bersemangat dan cenderung pasif dalam proses belajar mengajar, sehingga siswa kurang aktif dalam pembelajaran menulis. Selanjutnya teridentifikasi bahwa siswa dalam menulis karangan cenderung kesulitan merangkai kalimat yang satu dengan yang lainnya, atau pragraf yang satu dengan yang lainnya tidak koheren. Selain hal tersebut di atas, peneliti juga menemukan bahwa nilai rata-rata siswa dalam pembelajaran Bahasa Indonesia, khususnya dalam menulis karangan pada siswa kelas III yang berjumlah 35 orang adalah 6,35 yang kriteria ketuntasan minimal (KKM) adalah 7,00. Keterampilan menulis berbeda dengan jenis keterampilan berbahasa lainnya karena keterampilan menulis merupakan kegiatan berkomunikasi dengan menggunakan bahasa tulis sebagai medianya. Sejalan dengan itu, Abidin (2012:181) menyatakan bahwa menulis pada dasarnya adalah proses untuk mengemukakan ide dan gagasan dalam bahasa tulis. Menulis merupakan salah satu hal yang perlu dimiliki oleh siswa Sekolah Dasar, terutama pada siswa kelas awal, yaitu siswa kelas I sampai dengan kelas III. Akhadiah (Abidin 20I2: I8I) menyatakan bahwa "menulis adalah sebuah proses, yaitu proses penuangan gagasan atau ide ke dalam bahasa tulis, yang dalam praktiknya proses menulis diwujudkan dalam beberapa tahapan yang merupakan satu sistem yang utuh". Dengan memiliki kemampuan menulis, siswa dapat mengkomunikasikan ide, dan pengalamannya ke berbagai pihak. Sejalan dengan hal tersebut, maka menulis adalah kegiatan yang dilakukan oleh seseorang guna menuangkan gagasan ataupun pengalamannya dalam bentuk tulisan untuk disampaikan kepada pembaca, atau dengan kata lain menulis adalah alat komunikasi non verbal.

Agar pembelajaran menulis karangan dapat terlaksana dengan baik pada jenjang pendidikan sekolah dasar, diperlukan guru yang terampil untuk merancang dan mengelolah pembelajaran. Salah satu upaya yang dapat dilakukan oleh seorang guru dalam proses pembelajaran agar siswa lebih aktif, inovatif dan kreatif dalam pembelajaran Bahasa Indonesia khususnya dalam meningkatkan keterampilan menulis karangan yaitu dengan menggunakan media gambar berseri. Rahmawatiningsih (2010:5) “media gambar berseri merupakan suatu media visual yang berisi yakni urutan gambar, antara gambar yang satu dengan gambar yang lain saling berhubungan dan menyatakan 
suatu peristiwa”. Media gambar berseri mempunyai peranan yang cukup penting dalam membantu siswa meningkatkan keterampilan menulis karangan, karena dengan menggunakan media gambar berseri, siswa dapat melihat hubungan antara konsep, peristiwa, dan tokoh yang ada dalam pelajaran serta siswa dapat melihat hubungan antara komponen-komponen materi atau isi pelajaran yang diajarkan. Dengan bantuan media gambar berseri, guru akan lebih mudah mengatasi gangguan yang akan menghambat proses pembelajaran serta mampu meningkatkan hasil belajar keterampilan menulis karangan siswa kelas III SDN Sungai Andai I Kota Banjarmasin. Berdasarkan hal tersebut, maka tujuan penelitian ini adalah untuk mengetahui pengunaan media gambar berseri dalam meningkatkan keterampilan menulis karangan pada siswa kelas III SDN Sungai Andai I Kota Banjarmasin.

\section{METODOLOGI}

Pendekatan yang digunakan dalam penelitian ini adalah pendekatan kualitatif dan kuantitatif dengan jenis Penelitian Tindakan Kelas (Classroom Action Research) yang bertujuan untuk memperbaiki dan meningkatkan kualitas atau mutu pembelajaran di kelas, memecahkan suatu permasalahan di kelas, meningkatkan aktivitas dan hasil belajar atau meningkatkan kualitas guru. Sesuai yang dinyatakan Mulyasa (2011: 34) bahwa penelitian tindakan kelas merupakan suatu penelitian yang di mana guru bertujuan untuk melakukan perbaikan atau menemukan solusi atas berbagai masalah dealam kegiatan pembelajaran,dengan begitu kualitas dan layanan pembelajaran bagi siswa dapat ditingkatkan. Adapun 4 tahapan yang sering digunakan dalam penelitian tindakan kelas yaitu :

I) Perencanaan, yaitu mengembangkan rencana tindakan yang secara kritis berdasar permasalahan untuk meningkatkan apa yang telah terjadi, misalnya membuat rencana pelaksanaan pembelajaran (RPP), membuat Lembar Kerja
Siswa (LKS), dan menyusun alat evaluasi sesuai indikator hasil belajar.

2) Pelaksanaan Tindakan yaitu tindakan yang dilakukan secara sadar dan terkendali, yang merupakan variasi praktik yang cermat dan bijaksana untuk memperbaiki keadaan yang akan dilakukan.

3) Observasi, yaitu mendokumentasikan atau pengumpulan data yang berupa proses perubahan kinerja Proses Belajar Mengajar (PBM) observasi perlu direncanakan dan juga didasarkan dengan keterbukaan pandangan pikiran.

4) Refleksi, yaitu mengingat dan merenungkan suatu tindakan persis seperti yang dicatat dalam observasi. Refleksi (perenungan) merupakan kegiatan analisis, interpretasi (penjelasan) terhadap semua informasi yang diperoleh dari observasi atau pelaksanaan tindakan.

Penelitian tindakan kelas ini dilaksanakan pada mata pelajaran Bahasa Indonesia di kelas III SDN Sungai Andai I Kota Banjarmasin semester II tahun ajaran 2019/2020 dengan jumlah siswa 28 orang. Data yang dianalisis dalam penelitian tindakan kelas ini berupa data kualitatif dan kuantitatif yang terdiri dari: (a) Data kualitatif berupa data tentang aktivitas guru dalam kegiatan pembelajaran yang didapatkan dari observasi, (b) Data kuantitatif berupa nilai tes hasil belajar siswa melalui tes tertulis/evaluasi pada akhir kegiatan.

Indikator keberhasilan dalam penelitian tindakan kelas ini, yaitu (I) Aktivitas Guru, Aktivitas guru dalam pembelajaran dikategorikan berhasil apabila mencapai $\geq 80 \%$ dengan kategori sangat baik, dan (2) Aktivitas siswa, di keterampilan menulis karangan berhasil jika nilai rata-rata ketuntasan kelas $\geq 75 \%$ yang dilihat dari hasil belajar keterampilan menulis karangan dengan berbagai aspek dan kriteria ketuntasan yang telah ditetapkan melalui tes tertulis. 


\section{HASIL DAN PEMBAHASAN}

\section{Aktivitas Guru}

Berdasarkan hasil analisis data ditemukan bahwa kualitas aktivitas guru selama penelitian siklus I dan siklus II dapat dillihat perbandingannya pada observasi kegiatan pembelajaran pada tabel berikut ini :

Tabel I. Rekapitulasi Aktivitas Guru Siklus I dan Siklus II

\begin{tabular}{|c|c|c|}
\hline \multicolumn{3}{|c|}{ Aktivitas Guru } \\
\hline Siklus & Persentase & Kualifikasi \\
\hline I & $79.68 \%$ & Baik \\
\hline II & $85,93 \%$ & Sangat Baik \\
\hline
\end{tabular}

Berdasarkan tabel I.I tersebut dapat dilihat aktrivitas guru dalam kegiatan belajar mengajar terjadi peningkatan, terlihat pada siklus I persentase yang diperoleh $79,68 \%$ dengan kualifikasi baik. Sedangkan pada siklus II persentase yang diperoleh mencapai 85,93\% dengan kualifikasi sangat baik. Terlihat dari beberapa aspek kualitas dan kontribusi aktivitas guru yang berdampak sangat baik dalam menggunakan media gambar berseri seperti aspek guru melakukan apersepsi yang dikombinasikan ice breaking dengan sangat baik sesuai materi yang akan dipelajari, guru melakukan tanya jawab tentang gambar yang sudah diamati siswa sesuai dengan objek atau gambar berseri yang sudah diamati. Selanjutnya pada saat siswa menulis karangan, guru juga mengingatkan kembali tentang penggunaan huruf kapital dan tanda baca yang benar, memberikan pujian kepada siswa disetiap siswa membacakan hasil menulis karangan dan saat mengakhiri pembelajaran guru mengajak siswa untuk membuat kesimpulan pembelajaran dan mengakhiri pembelajaran dengan berdoa. Dimana kegiatan belajar pada hakikatnya merupakan rangakaian aktivitas siswa dan guru dalam mencapai tujuan pembelajaran. Dalam rangkaian aktivitas itu dimungkinkan membina satu, dua atau lebih dari aspek keterampilan proses pada siswa
(Hairuddin, dkk, 2007:2.9). Selanjutnya Brophy \& Wentzel (2014:250) menjelaskan bahwa:

Strategies for stimulating students' motivation to learn apply not only to their performance (work on tests or assignments) but also to their information-processing during learning (attending to lessons, reading for understand רing, comprehending explanations, putting things into their own words). Stimulating motivation to learn involves encouraging students to use thoughtful information-processing and skill-building strategies when they are learning.

Pernyataan Brophy mengandung arti bahwa strategi untuk merangsang motivasi peserta didik pada saat belajar, berlaku tidak hanya untuk kinerja peserta didik, namun berlaku juga pada saat (mengerjakan tes atau tugas), dimana merangsang motivasi belajar dan mampu mendorong peserta didik untuk menggunakan strategi pengolahan informasi dan strategi membangun proses dan keterampilan ketika mereka belajar. Maka pada siklus II sudah dianggap berhasil dan dapat meningkatkan aktivitas guru dan siswa dalam keterampilan menulis karangan menggunakan media gambar berseri.

\section{Hasil Belajar Siswa}

Berdasarkan hasil belajar siswa pada siklus I dan siklus II disajikan dalam bentuk tabel berikut ini :

\section{Tabel. 2 Rekapitulasi Rata-Rata dan Ketuntasan Hasil Belajar Keterampilan Menulis Siswa Siklus I dan Siklus II}

\begin{tabular}{|c|c|c|}
\hline $\begin{array}{c}\text { Hasil Belajar } \\
\text { Siswa }\end{array}$ & Siklus I & Siklus II \\
\cline { 2 - 3 } & Pert I & Pert I \\
\hline Ketuntasan & $\mathbf{7 1 , 4 2 \%}$ & $\mathbf{8 5 , 7 1 \%}$ \\
\hline
\end{tabular}

Berdasarkan tabel 2 pada siklus I dapat dilihat siswa masih belum mendapat hasil belajar yang diharapkan siswa masih kesulitan dalam materi pelajaran, serta sebagian siswa masih terlihat malumalu untuk membacakan hasil menulis karangan. Sehingga hasil belajar siswa belum berjalan dengan maksimal. Guru merefleksikan permasalahan tersebut 
dengan memotivasi siswa dalam untuk meningkatkan hasil belajar menulis karangan lebih baik lagi, guru memberi pemahaman serta arahan kepada siswa yang belum paham dengan pembelajaran, selain itu guru lebih memaksimalkan potensi diri dalam pengelolaan kelas online sesuai waktu dengan sangat baik. Pada pelaksanaan siklus I pertemuan pertama pada hasil belajar siswa persentase mencapai 71,42\% dengan kategori cukup aktif. Sedangkan pada siklus II persentase yang dicapai meningkat menjadi 85,71\% dengan kategori sangat aktif. Hasil belajar seseorang tergantung kepada apa yang telah diketahui mengenai konsep-konsep, tujuan dan motivasi yang mempengaruhi interaksi dengan bahan yang dipelajari (Suyono \& Hariyanto, 20II:127). Hasil belajar dikatakan meningkat apabila ditandai oleh dengan perubahan tingkah laku siswa secara keseluruhan, ketika pembelajaran berlangsung dan dalam berkelompok dengan berbagai strategi maupun media pembelajaran yang diterapkan. Hamalik (Arsyad, 2013:15) bahwa pemakaian media pembelajaran dalam proses pembelajaran dapat membangkitkan keinginan dan minat baru, meningkatkan motivasi dan rangsangan kegiatan belajar, dan dapat membawa pengaruh pengaruh psikologi terhadap siswa. Dimana penggunaan media gambar berseri sebagai media pembelajaran sejalan dengan Sudjana (2009:70) bahwa gambar dapat membantu siswa membangkitkan minatnya pada pembelajaran. Dengan demikian penelitian tindakan kelas dengan penerapan media gambar berseri dapat meningkatkan keterampilan menulis karangan bagi siswa kelas III SDN Sungai Andai I Kota Banjarmasin.

\section{KESIMPULAN DAN SARAN}

\section{KESIMPULAN}

Berdasarkan hasil penelitian keterampilan menulis karangan menggunakan media gambar berseri siswa kelas III SDN Sungai Andai I Kota Banjarmasin, dapat disimpukan sebagai berikut :
I. Aktivitas guru menggunakan media gambar berseri siswa kelas III SDN Sungai Andai I Kota Banjarmasin telah terlaksana dengan sangat baik, terlihat pada siklus I memperoleh persentase 79,68\% dengan kualifikasi baik meningkat pada siklus II mencapai 85,93\% dengan kualifikasi sangat baik.

2. Hasil belajar siswa dalam keterampilan menulis karangan menggunakan media gambar berseri siswa kelas III SDN Sungai Andai I Kota Banjarmasin telah terlaksana dengan sangat baik, terlihat pada siklus I memperoleh persentase ketuntasan 7I,42\% dengan kategori cukup aktif meningkat pada siklus II mencapai 85,7I\% dengan kategori sangat aktif.

\section{SARAN}

Berdasarkan hasil penelitian, pembahasan, dan kesimpulan yang telah diuraikan dapat dikemukakan beberapa saran, sebagai berikut :

I. Kepada Kepala Sekolah disarankan dapat membina guru - guru di sekolah dalam pertimbangan pemilihan media gambar sebagai inovasi dalam materi pembelajaran

2. Kepada guru disarankan dapat menggunakan media gambar berseri sebagai salah satu alternatif media pembelajaran dalam meningkatkan keterampilan menulis

3. Kepada siswa disarankan untuk lebih meningkatkan keterampilan menulis karangan agar mencapai hasil belajar yang maksimal.

\section{REFERENSI}

Abidin, Yunus. 2012. Pembelajaran Bahasa Berbasis Pendidikan Karakter. Bandung: Refika Aditama

Arsyad, A. 2013. Media Pembelajaran. Jakarta:Rajawali Pers.

Brophy, J.E \& Wentzel, K.R. (20|4). Motivating students to learn fourth edition. New York: Routledge.

Dalman, H. 20II. Kerampilan Menulis. Jakarta:Rajawali Pers. 
Hairuddin, dkk. 2007. Pembelajaran Bahasa Indonesia.

Direktorat Jendral Pendidikan Tinggi

Departemen Pendidikan Nasional, Jakarta.

Mulyasa, H.E. 20II. Praktik Penelitian Tindakan Kelas. Bandung: PT Remaja Rosdakarya Offset.

Ramadhani, M.I \& Fuady, R. (2020). Meningkatkan Hasil Belajar IPS Materi Persiapan Kemerdekaan Indonesia Melalui Model Pembelajaran Think Pair and Share (TPS) divariasikan dengan Model Pembelajaran Talking Stick Siswa Kelas V SDN Pasayangan 3 Martapura Kabupaten Banjar. Jurnal Pahlawan. Vol.16 No 01, I02-II2.

Sudjana. 2009. Media Pembelajaran (Penggunaan dan Pembuatannya). Bandung: Sinar Baru Algensindo Suyono dan Hariyanto. 20II. Belajar dan Pembelajaran. Bandung: PT Remaja Rosdakarya Offset. 